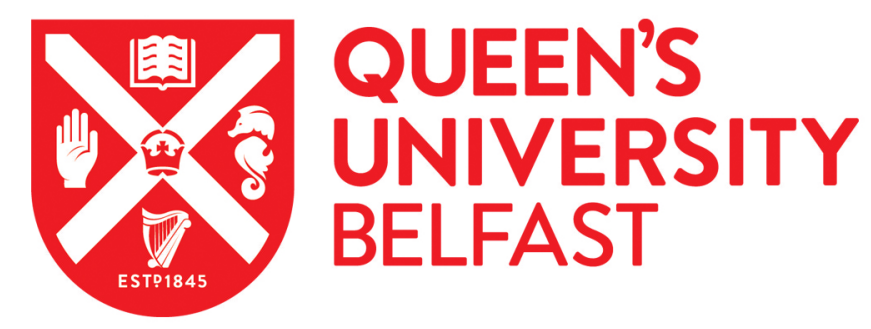

\title{
Arsenic uptake by arbuscular mycorrhizal maize (Zea mays L.) grown in an arsenic-contaminated soil with added phosphorus
}

Xia, Y. S., Chen, B. D., Christie, P., Smith, F. A., Wang, Y. S., \& Li, X. L. (2007). Arsenic uptake by arbuscular mycorrhizal maize (Zea mays L.) grown in an arsenic-contaminated soil with added phosphorus. Journal of Environmental Sciences, 19(10), 1145-1251. https://doi.org/10.1016/S1001-0742(07)60203-4

Published in:

Journal of Environmental Sciences

Queen's University Belfast - Research Portal:

Link to publication record in Queen's University Belfast Research Portal

\section{General rights}

Copyright for the publications made accessible via the Queen's University Belfast Research Portal is retained by the author(s) and / or other copyright owners and it is a condition of accessing these publications that users recognise and abide by the legal requirements associated with these rights.

Take down policy

The Research Portal is Queen's institutional repository that provides access to Queen's research output. Every effort has been made to ensure that content in the Research Portal does not infringe any person's rights, or applicable UK laws. If you discover content in the Research Portal that you believe breaches copyright or violates any law, please contact openaccess@qub.ac.uk. 


\title{
Arsenic uptake by arbuscular mycorrhizal maize (Zea mays L.) grown in an arsenic-contaminated soil with added phosphorus
}

\author{
XIA Yun-sheng ${ }^{1,2}$, CHEN Bao-dong ${ }^{2}$, CHRISTIE Peter ${ }^{3}$, SMITH F Andrew $^{4}$, \\ WANG You-shan ${ }^{5}$, LI Xiao-lin ${ }^{1, *}$
}

\begin{abstract}
1. College of Resources and Environmental Sciences, China Agricultural University, Beijing 100094, China. E-mail: yshengxia@163.com 2. Department of Soil Environmental Science, Research Center for Eco-Environmental Sciences, Chinese Academy of Sciences, Beijing 100085, China 3. Agricultural and Environmental Science Department, Queen's University Belfast, Belfast, BT9 5PX, UK

4. Soil and Land Systems, School of Earth and Environmental Sciences, Waite Campus, The University of Adelaide, South Australia 5005, Australia

5. Institute of Plant Nutrition and resources, Beijing Municiple Academy of Agriculture and Forestry Sciences, Beijing 100097, China
\end{abstract}

Received 12 December 2006; revised 30 January 2007; accepted 28 February 2007

\begin{abstract}
The effects of arbuscular mycorrhizal (AM) fungus (Glomus mosseae) and phosphorus (P) addition (100 mg/kg soil) on arsenic (As) uptake by maize plants (Zea mays L.) from an As-contaminated soil were examined in a glasshouse experiment. Non-mycorrhizal and zero-P addition controls were included. Plant biomass and concentrations and uptake of As, $\mathrm{P}$, and other nutrients, AM colonization, root lengths, and hyphal length densities were determined. The results indicated that addition of $\mathrm{P}$ significantly inhibited root colonization and development of extraradical mycelium. Root length and dry weight both increased markedly with mycorrhizal colonization under the zero-P treatments, but shoot and root biomass of AM plants was depressed by P application. AM fungal inoculation decreased shoot As concentrations when no $\mathrm{P}$ was added, and shoot and root As concentrations of AM plants increased 2.6 and 1.4 times with $\mathrm{P}$ addition, respectively. Shoot and root uptake of $\mathrm{P}, \mathrm{Mn}, \mathrm{Cu}$, and $\mathrm{Zn}$ increased, but shoot Fe uptake decreased by $44.6 \%$, with inoculation, when $\mathrm{P}$ was added. $\mathrm{P}$ addition reduced shoot $\mathrm{P}, \mathrm{Fe}, \mathrm{Mn}, \mathrm{Cu}$, and $\mathrm{Zn}$ uptake of $\mathrm{AM}$ plants, but increased root $\mathrm{Fe}$ and $\mathrm{Mn}$ uptake of the nonmycorrhizal ones. AM colonization therefore appeared to enhance plant tolerance to As in low $\mathrm{P}$ soil, and have some potential for the phytostabilization of As-contaminated soil, however, $\mathrm{P}$ application may introduce additional environmental risk by increasing soil As mobility.
\end{abstract}

Key words: arsenic; arbuscular mycorrhiza; phosphate; maize; phytostabilization

\section{Introduction}

In recent years the arsenic (As) concentrations in many soils have been substantially elevated because of irrigation with As-rich groundwater or anthropogenic activities, such as, ore mining, non-ferrous metal smelting, coal combustion, use of As-based pesticides, and application of municipal sewage sludge (Smith et al., 1998; Acharyya et al., 1999; Lambkin and Alloway, 2003). The use of As-contaminated ground water has resulted in widespread As-related diseases in South-east Asia. In some areas of Inner Mongolia, Xinjiang, Taiwan, Hunan, and Shanxi provinces in China, soils are also moderately or heavily contaminated (Cai et al., 2004).

After entering the plant, As can disturb plant metabolism, as arsenate decouples phosphorylation in mitochondria and arsenite inactivates many enzymes by reacting with sulphydryl groups of proteins (Dixon, 1997). As a chemical analogue of phosphate, As competes with $\mathrm{P}$ in the soil, and during plant uptake from the external

Project supported by the National Natural Science Foundation of China (No. 40401031).*Corresponding author. E-mail: lixl@cau.edu.cn. solution, because both elements are taken up via the phosphate transport systems (Meharg and Macnair, 1990; Cao et al., 2003). On the other hand, phosphate may also have a direct effect on As speciation in soil and may enhance As phytoavailability (Melamed et al., 1995; Peryea and Kammereck, 1997).

It is well known that arbuscular mycorrhizal (AM) fungi are ubiquitous in natural and agricultural ecosystems (Harley, 1989; Smith and Read, 1997). Some studies have shown that higher plants that have adapted to As-polluted soils are generally associated with mycorrhizal fungi (Meharg and Cairney, 1999; Sharples et al., 2000a, b; Gonzalez-Chavez et al., 2002). Recently it has been demonstrated that mycorrhizas and phosphate fertilizers can protect plants grown in As-contaminated soils. The mechanisms proposed include the tolerance of higher plants to arsenate through downregulated arsenate/phosphate transporters in the epidermis and root hairs (Meharg and Macnair, 1992; Gonzalez-Chavez et al., 2002), to reduce the uptake of As, and upregulated low affinity of phosphate transporters located in the membrane fraction of mycorrhizal roots (Harrison et al., 
2002), to take up more $P$ for better growth. The ericoid mycorrhizal fungus Hymenoscyphus ericae from an As and $\mathrm{Cu}$ mine spoil has adapted to arsenate contamination and acts as a filter to maintain low plant As levels through arsenite efflux (Sharples et al., 2000a). However, even up to now, little is known about the involvement of AM fungus in P-As interactions in the plant-soil continuum under As contaminations, and evidence is lacking for the possible combination of agricultural practices, such as, fertilizer application, with mycorrhizal technology for effective restoration of contaminated sites. Therefore, the authors conducted this preliminary study to investigate the effects of AM fungi and P fertilizer on the uptake of As and other nutrients, using maize plants growing in a soil collected from the As mining area. They particularly aimed to evaluate the effects of the mycorrhizal fungus and $\mathrm{P}$ addition on plant adaptation to As contamination, and to reveal the potential role of AM fungi in ecological restoration of As contaminated soil.

Maize (Zea mays L.) was selected as a test plant in this study, because it was observed that this crop was grown in a local area and suffered from As toxicity. It was therefore logical to investigate the role of AM fungus in plant adaptation to As contaminated soils using this plant species.

\section{Materials and methods}

\subsection{Cultivation media}

The As-contaminated soil was collected from a miningimpacted area near the As mine tailings, at Shimen City, Hunan Province. A mixture of soil and river sand (2:1 w/w soil: sand, henceforth referred to as "soil") was used in the experiment. The substrate was passed through a $2-\mathrm{mm}$ sieve, sterilized by $\gamma$-irradiation $(20 \mathrm{kGy}, 20 \mathrm{MeV}$ electron beam). The soil consisted of $2.77 \%$ clay $(<2 \mu \mathrm{m}), 71.83 \%$ loam $(>2 \mu \mathrm{m},<50 \mu \mathrm{m})$, and $25.40 \%$ sand $(>50 \mu \mathrm{m}$, $<2000 \mu \mathrm{m}$ ), and characterized as silt loam. It had a $\mathrm{pH}$ of 7.60 (soil in water, $1: 2.5, \mathrm{~m} / \mathrm{v}$ ), a water-extractable $\mathrm{P}$ content of $5.28 \mathrm{mg} / \mathrm{kg}$, and a water-extractable As of 82.66 $\mathrm{mg} / \mathrm{kg}$ (soil in water $(1: 10, \mathrm{~m} / \mathrm{v}$ ) extraction for $30 \mathrm{~min}$, measured by inductively coupled plasma-optical emission spectrometry (ICP-OES; Vista-MPX, Varian, USA)). The total $\mathrm{P}$ and As contents (soil digested with a mixture of concentrated $\mathrm{HNO}_{3}$ and $\mathrm{HCl}$, and $\mathrm{HClO}_{4}$ ) were 392.16 and $1204.99 \mathrm{mg} / \mathrm{kg}$ respectively. Organic matter content of the soil was $12.51 \mathrm{~g} / \mathrm{kg}$, and the cation exchange capacity (CEC) was $9.81 \mathrm{cmol} / \mathrm{kg}$.

\subsection{Host plant and AM fungus}

Seeds of maize plants (Z. mays cv. ND108) were surface sterilized in a solution of $10 \%(\mathrm{v} / \mathrm{v}) \mathrm{H}_{2} \mathrm{O}_{2}$ for $10 \mathrm{~min}$, then immersed in demonized water for $6 \mathrm{~h}$. They were germinated on moist filter paper overnight at $25^{\circ} \mathrm{C}$. The AM fungus Glomus mossese $\mathrm{BGCXJ02}$ did not have a background of As tolerance. It was propagated in pot culture on maize plants grown in a sandy soil for 10 weeks. Inoculum from the pot culture comprised of a mixture of spores, mycelium, sandy soil, and maize root fragments. Every $10 \mathrm{~g}$ of inoculum contained around 120 fungal spores.

\subsection{Glasshouse experiment}

The experiment was conducted in the glasshouse of the Research Center for Eco-Environmental Sciences, Chinese Academy of Sciences, Beijing. The temperature regime was $25 \pm 3^{\circ} \mathrm{C} / 20 \pm 2^{\circ} \mathrm{C}$ day/night and with natural light. The $\mathrm{P}$ addition level was $100 \mathrm{mg} / \mathrm{kg}$. In addition, the basal nutrients ( $\mathrm{N}: 90 \mathrm{mg} / \mathrm{kg}$; K: $125 \mathrm{mg} / \mathrm{kg}$ ) were added to the soil to ensure healthy plant growth. Plants in soil with or without $\mathrm{P}$ addition were inoculated with $G$. mossese or uninoculated. There were four treatments in triplicate, making it a total of 12 pots in a complete randomized block design. Cultivation pots were made of PVC tubes $(\varnothing 7 \mathrm{~cm} \times 15 \mathrm{~cm})$. Eighteen grams of inoculum and $600 \mathrm{~g}$ of amended soil were filled in each pot. After the amended soil had been stored for two weeks to equilibrate, two pregerminated seeds were selected for uniformity of size and sown in each pot and the seedlings were thinned to one per pot after seven days. The plants grew for seven weeks from 9 March to 28 April, 2004. Soil moisture content was adjusted regularly to $70 \%$ water holding capacity (WHC) with deionized water, throughout the experiment.

\subsection{Harvest and chemical analysis}

Shoots and roots were harvested separately. Samples were carefully washed with deionized water to remove adhering soil particles. Subsamples of fresh roots were collected and cut into segments approximately $1 \mathrm{~cm}$ long, cleared with $10 \%(\mathrm{w} / \mathrm{v}) \mathrm{KOH}$ in a water bath at $90^{\circ} \mathrm{C}$ for $15 \mathrm{~min}$, and stained with Trypan blue, to estimate the proportion of root length colonized by the mycorrhizal fungus (Phillips and Hayman, 1970). The dry weights of shoots and roots were determined after oven drying at $70^{\circ} \mathrm{C}$ for $48 \mathrm{~h}$. Oven-dried plant samples were milled to pass through a $0.5-\mathrm{mm}$ sieve. Subsamples were digested in $5 \mathrm{ml}$ of concentrated $\mathrm{HNO}_{3}(\mathrm{GR})$, first at $80^{\circ} \mathrm{C}$ for $2 \mathrm{~h}$ and then at $120^{\circ} \mathrm{C}$ for $30 \mathrm{~h}$. After digestion the solutions were cooled, diluted to $50 \mathrm{ml}$ using ultra-pure water, filtered into acid-washed plastic bottles, and the As, P, Fe, Mn, $\mathrm{Cu}$, and $\mathrm{Zn}$ concentrations were determined by ICP-OES (Optima 2000DV, Perkin Elmer Co. USA). A standard reference material (bush twigs and leaves (GBW07603 (GSV-2)) obtained from the Chinese Standard Materials Center was used to assure the accuracy and precision of the digestion and analysis procedures. The soils in the pots were sampled at the end of the experiment, air-dried, and passed through a 2-mm sieve. The percentage of the total root length colonized by the AM fungus was determined using the gridline intersect technique (Giovannetti and Mosse, 1980). The length of the extraradical mycelium in soil was determined by a modified and combined method according to Jones et al. (1998) and Newman (1966). The specific absorption rate (SAR) was defined as the amount of nutrients absorbed per unit of root mass and was calculated as follows: SAR = Plant nutrient uptake ( $\mu \mathrm{g}) /$ Root mass (mg) (Azcón et al., 2003). 


\subsection{Data analysis}

All results are expressed as means and the standard errors (SE) of the three replicates and the effects of the mycorrhizal status and $\mathrm{P}$ addition were examined by using the two-way analysis of variance with the GenStat for PC/Windows version 6.1 statistical package (GenStat Committee, 2002). The least significant differences (LSD) at the 5\% level was calculated to compare means across the P levels, when there were significant interactions of inoculation treatment with $\mathrm{P}$ addition, or to compare means under the same P level, when no significant interaction was recorded.

\section{Results}

\subsection{Colonization of maize roots and soil by $G$. mosseae}

No root infection was detected in the uninoculated plants, but roots of the inoculated plants were extensively colonized by G. mosseae (Table 1). There was a significantly negative effect of $\mathrm{P}$ addition on root colonization $(P$ $<0.05)$, and hyphal length density also declined when $\mathrm{P}$ was added to the soil $(P<0.05)$.

Table 1 Infection rate of maize roots and hyphal length density in soil at the experimental harvest

\begin{tabular}{llll}
\hline $\begin{array}{l}\text { Inoculation } \\
\text { treatment }\end{array}$ & $\begin{array}{l}\text { P addition } \\
\text { level }(\mathrm{mg} / \mathrm{kg})\end{array}$ & $\begin{array}{l}\text { Root infection } \\
\text { rate }(\%)\end{array}$ & $\begin{array}{l}\text { Hyphal length } \\
\text { density }(\mathrm{m} / \mathrm{g})\end{array}$ \\
\hline Uninoculated & 0 & $0 \pm 0^{\mathrm{c} *}$ & $0.3 \pm 0.1^{\mathrm{c}}$ \\
Inoculated & 100 & $0 \pm 0^{\mathrm{c}}$ & $0.2 \pm 0.1^{\mathrm{c}}$ \\
& 0 & $51.6 \pm 6.2^{\mathrm{a}}$ & $4.5 \pm 0.2^{\mathrm{a}}$ \\
& 100 & $26.2 \pm 6.0^{\mathrm{b}}$ & $1.8 \pm 0.3^{\mathrm{b}}$ \\
\hline
\end{tabular}

*Means \pm SE $(n=3)$ in the same column with different letters differ significantly $(P<0.05)$.

\subsection{Plant growth}

Generally, $\mathrm{P}$ addition decreased plant dry weight and total root length $(P<0.001)$. On the other hand, shoot and root dry weights and root length markedly increased with AM fungal inoculation when no $\mathrm{P}$ was added $(P$ $<0.05)$, but were unaffected by inoculation when $P$ was added (Fig.1).

\subsection{As and $P$ uptake and $P / A s$ ratios}

Mycorrhizal colonization led to an increased As uptake in both shoots and roots $(P<0.05)$, but decreased shoot As concentrations when $\mathrm{P}$ was not added, whereas, when $\mathrm{P}$ was added to the soil shoot and root As concentrations and uptake were higher in mycorrhizal plants $(P<0.05)$ (Figs.2 and 3). Phosphorus addition significantly increased As concentrations in shoots and roots of AM plants $(P$ $<0.001)$, but decreased As uptake by the roots $(P<$ 0.05 ) (Figs.2 and 3). In nonmycorrhizal plant roots, $P$ addition increased the As concentrations $(P<0.001)$, but had little effect on As uptake. The shoot to root ratios of As uptake ranged from 0.029 to 0.057 , indicating that only a very small fraction of the As taken up by the roots was translocated to the shoots. Furthermore, the ratios

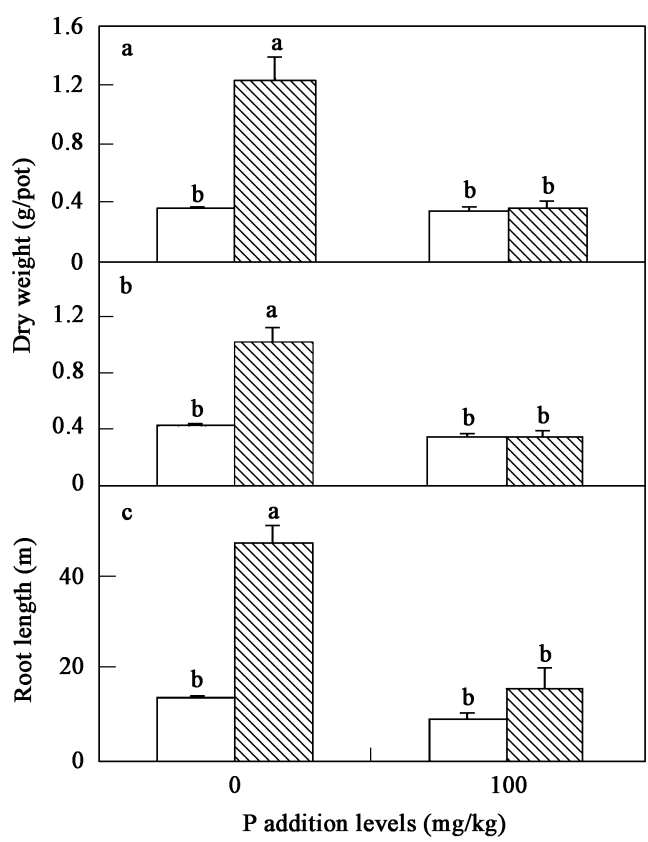

Fig. 1 Shoot (a), root (b) dry weights and root lengths (c) of maize plants grown in As-contaminated soil under different P levels. Open columns, uninoculated controls, and solid columns, inoculated with G. mosseae. Different letters above the columns indicate significant differences between inoculation treatments across the P levels by LSD test at the 5\% level. Error bars: standard errors $(n=3)$.

decreased with AM inoculation when $\mathrm{P}$ was not added, but increased markedly with $\mathrm{P}$ addition (data not shown).

Shoot and root $\mathrm{P}$ concentrations and uptake were significantly higher in inoculated plants compared with nonmycorrhizal controls $(P<0.001)$ (Figs.2 and 3). Phosphorus addition showed no effect on shoot $\mathrm{P}$ concentrations, but increased root $\mathrm{P}$ concentrations irrespective of inoculation treatment $(P<0.001)$ (Fig.2). Shoot and root $\mathrm{P}$ uptake by AM plants decreased significantly with $\mathrm{P}$ addition $(P<0.01)$, but added $\mathrm{P}$ had no effect on nonmycorrhizal controls (Fig.3).

$\mathrm{P} /$ As ratios in maize shoots were much higher than those in roots. Mycorrhiza significantly increased $\mathrm{P} / \mathrm{As}$ ratios in maize roots irrespective of $\mathrm{P}$ addition, whereas, the ratios in shoots were increased by mycorrhiza only in case no $\mathrm{P}$ was added (Table 2). On the other hand, $\mathrm{P}$ addition slightly increased $\mathrm{P} / \mathrm{As}$ ratios in uninoculated plants, but markedly decreased those ratios in inoculated plants.

\subsection{Plant uptake of other nutrients}

Root Fe concentrations were elevated both by mycorrhizal inoculation and by $\mathrm{P}$ addition $(P<0.001)$. $\mathrm{P}$ additions also significantly increased shoot Fe concentrations $(P<0.001)$, whereas, the shoot Fe concentrations were significantly lower in AM plants than in nonmycorrhizal controls $(P<0.001)$ (Table 3). As for Fe uptake, when no $\mathrm{P}$ was added to the soil, mycorrhiza increased both shoot and root Fe uptake; but when $\mathrm{P}$ was added, only root Fe uptake was increased by mycorrhiza. Addition of $\mathrm{P}$ decreased the shoot uptake of $\mathrm{Mn}, \mathrm{Cu}$, and $\mathrm{Zn}$ by AM plants $(P<0.01)$, but increased their concentrations in the roots $(P<0.05)$ (Table 3$)$. Irrespective of $\mathrm{P}$ addition, 


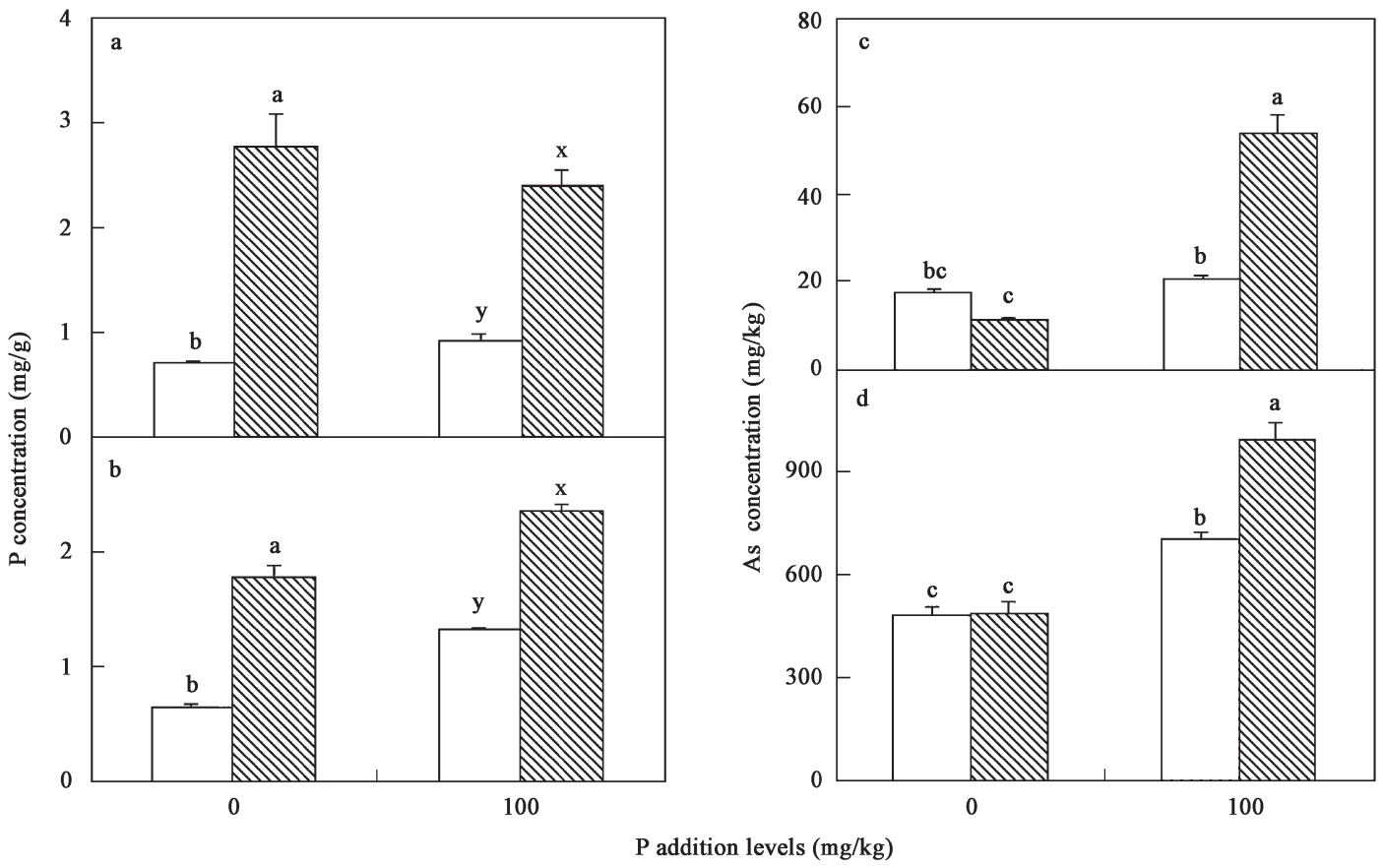

Fig. $2 \mathrm{P}$ and As concentrations in shoots $(\mathrm{a}, \mathrm{c})$ and roots $(\mathrm{b}, \mathrm{d})$ of maize plants grown in As-contaminated soil under different P levels. Open columns, uninoculated controls, and solid columns, inoculated with G. mosseae. Different letters above the columns indicate significant differences between inoculation treatments across the P levels by LSD test at the 5\% level. Error bars: standard errors $(n=3)$.

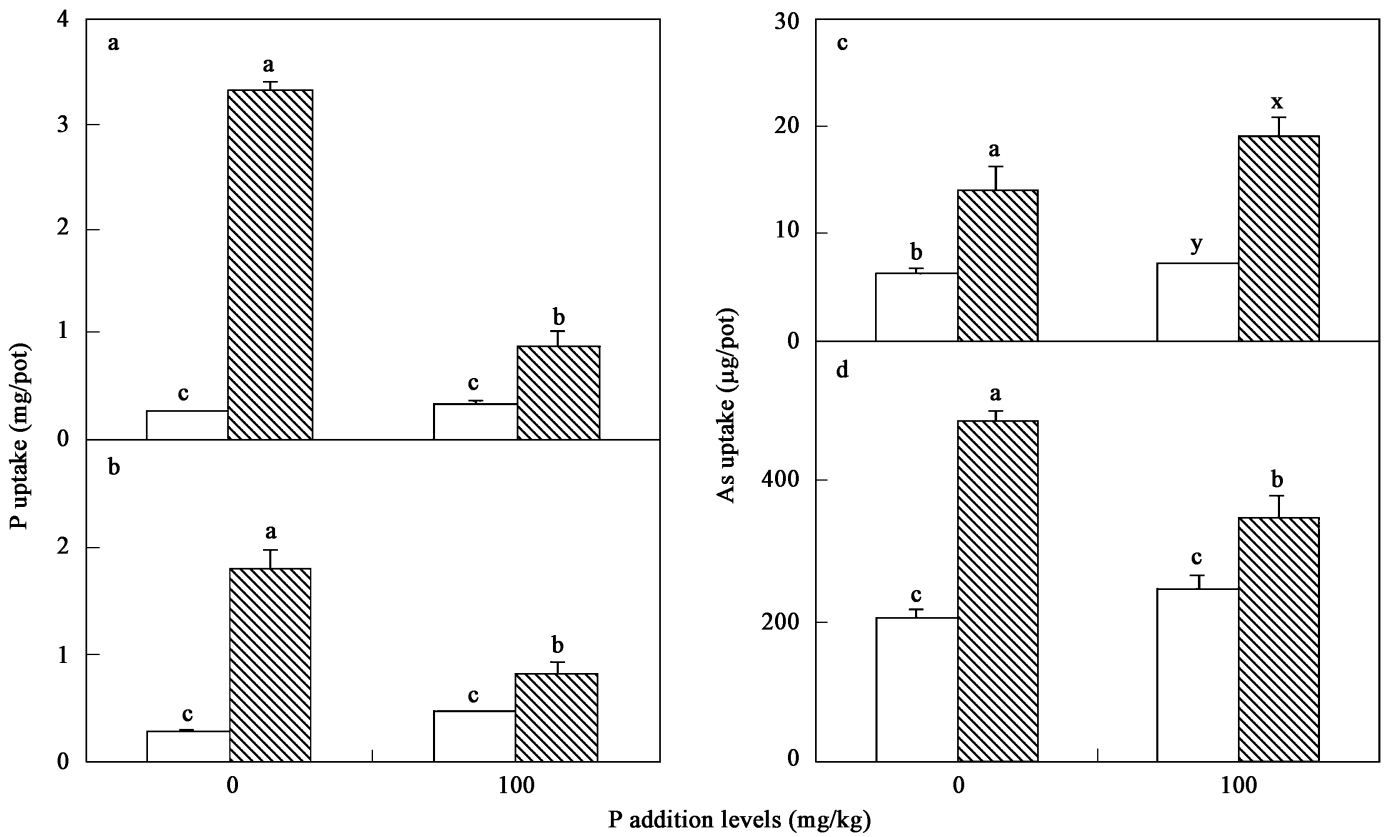

Fig. $3 \mathrm{P}$ and As uptake by shoots (a, c) and roots (b, d) of maize plants grown in As-contaminated soil with different P levels. Open columns, uninoculated controls; and solid columns, inoculated with $G$. mosseae. Different letters above the columns indicate significant differences between inoculation treatments across the P levels by LSD test at the 5\% level. Error bars: standard errors $(n=3)$.

Table 2 SAR of $P$ and As, and uptake ratio of $P$ to As in maize plants grown in As-contaminated soil under different $P$ levels

\begin{tabular}{|c|c|c|c|c|c|}
\hline \multirow[t]{2}{*}{ Inoculation treatment } & \multirow[t]{2}{*}{ P level (mg/kg) } & \multicolumn{2}{|c|}{$\mathrm{SAR}(\mu \mathrm{g} / \mathrm{mg})$} & \multicolumn{2}{|c|}{ Uptake ratio of $\mathrm{P}$ to As } \\
\hline & & $\mathrm{P}$ & As & Shoot & Root \\
\hline \multirow[t]{2}{*}{ Uninoculated } & 0 & $1.25^{\mathrm{c}^{*}}$ & $0.49^{c}$ & $41.1^{\mathrm{b}}$ & $1.37^{\mathrm{d}}$ \\
\hline & 100 & $2.24^{\mathrm{b}}$ & $0.72^{b}$ & $45.0^{\mathrm{b}}$ & $1.88^{\mathrm{c}}$ \\
\hline \multirow[t]{2}{*}{ Inoculated } & 0 & $5.09^{\mathrm{a}}$ & $0.50^{\mathrm{c}}$ & $245.5^{\mathrm{a}}$ & $3.70^{\mathrm{a}}$ \\
\hline & 100 & $4.83^{\mathrm{a}}$ & $1.05^{\mathrm{a}}$ & $45.6^{\mathrm{b}}$ & $2.38^{b}$ \\
\hline
\end{tabular}

* Means $(n=3)$ in the same column with different letters differ significantly $(P<0.05)$. 
Table $3 \mathrm{Fe}, \mathrm{Mn}, \mathrm{Cu}$, and $\mathrm{Zn}$ concentrations in and uptake by maize plants grown in As-contaminated soil under different $\mathrm{P}$ levels

\begin{tabular}{|c|c|c|c|c|c|c|}
\hline & \multirow{2}{*}{$\begin{array}{l}\text { Inoculation } \\
\text { treatment }\end{array}$} & \multirow{2}{*}{$\begin{array}{l}\text { P level } \\
(\mathrm{mg} / \mathrm{kg})\end{array}$} & \multicolumn{2}{|c|}{$\mathrm{Fe}$} & \multicolumn{2}{|c|}{$\mathrm{Mn}$} \\
\hline & & & Conc. (mg/kg) & Uptake $(\mu \mathrm{g} / \mathrm{kg})$ & Conc. $(\mathrm{mg} / \mathrm{kg})$ & Uptake $(\mu \mathrm{g} / \mathrm{kg})$ \\
\hline \multirow[t]{4}{*}{ Shoots } & \multirow[t]{2}{*}{ Uninoculated } & 0 & $201 \pm 9^{a^{*}}$ & $74 \pm 5^{b}$ & $70.6 \pm 2.4^{b}$ & $25.6 \pm 1.0^{\mathrm{b}}$ \\
\hline & & 100 & $246 \pm 4^{x}$ & $87 \pm 4^{\mathrm{ab}}$ & $50.3 \pm 4.2^{\mathrm{c}}$ & $17.6 \pm 1.4^{\mathrm{b}}$ \\
\hline & \multirow[t]{2}{*}{ Inoculated } & 0 & $95 \pm 2^{\mathrm{b}}$ & $118 \pm 17^{\mathrm{a}}$ & $63.1 \pm 1.8^{\mathrm{bc}}$ & $78.0 \pm 11.5^{\mathrm{a}}$ \\
\hline & & 100 & $140 \pm 6^{y}$ & $50 \pm 5^{b c}$ & $91.4 \pm 5.5^{\mathrm{a}}$ & $33.3 \pm 3.6^{\mathrm{b}}$ \\
\hline \multirow[t]{6}{*}{ Roots } & \multirow[t]{2}{*}{ Uninoculated } & 0 & $1296 \pm 42^{b}$ & $559 \pm 36^{\mathrm{c}}$ & $21.5 \pm 0.2^{\mathrm{c}}$ & $9.2 \pm 0.4^{\mathrm{b}}$ \\
\hline & & 100 & $2431 \pm 204^{y}$ & $841 \pm 25^{\mathrm{bc}}$ & $51.1 \pm 7.2^{\mathrm{b}}$ & $17.6 \pm 1.5^{\mathrm{y}}$ \\
\hline & \multirow[t]{2}{*}{ Inoculated } & 0 & $2018 \pm 92^{\mathrm{a}}$ & $2051 \pm 219^{a}$ & $46.6 \pm 0.5^{\mathrm{b}}$ & $47.4 \pm 4.6^{\mathrm{a}}$ \\
\hline & & 100 & $3364 \pm 70^{x}$ & $1176 \pm 94^{b}$ & $146.2 \pm 7.2^{\mathrm{a}}$ & $51.7 \pm 6.3^{x}$ \\
\hline & \multirow{2}{*}{$\begin{array}{l}\text { Inoculation } \\
\text { treatment }\end{array}$} & \multirow{2}{*}{$\begin{array}{l}\text { P level } \\
(\mathrm{mg} / \mathrm{kg})\end{array}$} & \multicolumn{2}{|c|}{$\mathrm{Cu}$} & \multicolumn{2}{|c|}{$\mathrm{Zn}$} \\
\hline & & & Conc. (mg/kg) & Uptake $(\mu \mathrm{g} / \mathrm{kg})$ & Conc. $(\mathrm{mg} / \mathrm{kg})$ & Uptake $(\mu \mathrm{g} / \mathrm{kg})$ \\
\hline \multirow[t]{4}{*}{ Shoots } & \multirow[t]{2}{*}{ Uninoculated } & 0 & $3.7 \pm 0.2^{\mathrm{b}}$ & $1.4 \pm 0.1^{\mathrm{bc}}$ & $23.4 \pm 2.2^{b c}$ & $8.6 \pm 1.1^{\mathrm{bc}}$ \\
\hline & & 100 & $2.7 \pm 0.4^{\mathrm{y}}$ & $0.9 \pm 0.2^{\mathrm{c}}$ & $15.1 \pm 0.4^{\mathrm{c}}$ & $5.3 \pm 0.3^{c}$ \\
\hline & \multirow[t]{2}{*}{ Inoculated } & 0 & $6.6 \pm 0.6^{\mathrm{a}}$ & $8.0 \pm 0.4^{\mathrm{a}}$ & $54.8 \pm 6.7^{\mathrm{a}}$ & $65.2 \pm 1.3^{\mathrm{a}}$ \\
\hline & & 100 & $5.1 \pm 0.3^{x}$ & $1.9 \pm 0.3^{b}$ & $29.3 \pm 0.7^{b}$ & $10.8 \pm 1.4^{\mathrm{b}}$ \\
\hline \multirow[t]{4}{*}{ Roots } & \multirow[t]{2}{*}{ Uninoculated } & 0 & $4.4 \pm 0.3^{\mathrm{b}}$ & $1.9 \pm 0.2^{\mathrm{c}}$ & $13.8 \pm 1.1^{\mathrm{c}}$ & $5.9 \pm 0.7^{\mathrm{c}}$ \\
\hline & & 100 & $7.4 \pm 0.8^{y}$ & $2.5 \pm 0.2^{\mathrm{c}}$ & $18.5 \pm 1.8^{\mathrm{b}}$ & $6.4 \pm 0.3^{c}$ \\
\hline & \multirow[t]{2}{*}{ Inoculated } & 0 & $15.5 \pm 0.8^{\mathrm{a}}$ & $15.8 \pm 1.7^{\mathrm{a}}$ & $18.0 \pm 1.3^{b c}$ & $18.3 \pm 2.4^{\mathrm{a}}$ \\
\hline & & 100 & $18.1 \pm 2.2^{\mathrm{x}}$ & $6.3 \pm 0.5^{\mathrm{b}}$ & $33.2 \pm 1.3^{\mathrm{a}}$ & $11.5 \pm 0.8^{\mathrm{b}}$ \\
\hline
\end{tabular}

*For shoots or roots respectively, means $\pm \mathrm{SE}(n=3)$ in same column with different letters differ significantly $(P<0.05)$.

mycorrhizal inoculation increased root $\mathrm{Mn}, \mathrm{Cu}$, and $\mathrm{Zn}$ concentrations and uptake with, the only exception of root Zn concentration.

\subsection{Soil $\mathrm{pH}$ and water extractable $\mathrm{P}$ and $\mathrm{As}$}

Soil $\mathrm{pH}$ values were generally higher in inoculated pots than those in uninoculated controls $(P<0.001)$, whereas, $\mathrm{P}$ addition tended to decrease soil $\mathrm{pH}$, especially for uninoculated pots $(P<0.05)$ (Table 4$)$. When no $\mathrm{P}$ was added to the soil, concentrations of water extractable $\mathrm{P}$ was lower in inoculated pots, and the contrary when $\mathrm{P}$ was added (Table 4), whereas, concentrations of water extractable As were significantly increased by both mycorrhizal inoculation and $\mathrm{P}$ addition.

\section{Discussion}

Gonzalez-Chavez et al. (2002), demonstrated for the first time that AM fungi could reduce arsenate influx into both arsenate resistant and nonresistant Holcus lanatus plants. AM fungal colonization of $H$. lanatus might suppress the high-affinity phosphate transport system. More recent studies indicated that colonization by $G$. mosseae could lower shoot As concentrations and markedly increase P/As ratios in the host plants (Liu et al., 2005; Chen et al., 2006, 2007). Consistently, the present study confirmed these mycorrhizal effects in maize plants (Table 2), furthermore, mycorrhiza enhanced As uptake by maize regardless of soil $\mathrm{P}$ supply, although the SAR of As remained unaffected when $\mathrm{P}$ was not added (Table 2 ). This could be explained by higher water-soluble As concentrations in inoculated pots than in the uninoculated controls, because of an increase in soil pH (Table 4) (Fitz and Wenzel, 2002), and by the larger biomass of the AM plants when the soil was not amended with P (Fig.1). These results further suggested that colonization by G. mosseae might not downregulate arsenate/phosphate transporters in the maize roots, but could assist the host plant in the uptake of sufficient $\mathrm{P}$, by upregulating low-affinity phosphate transporters located in the mycorrhizal roots (Harrison et al., 2002; Chen et al., 2007), thereby resulting in the enhanced arsenate resistance of host plants. It is interesting to note that mycorrhizal colonization had little effect on the maize biomass with $\mathrm{P}$ addition, in spite of the increase in root $\mathrm{P} / \mathrm{As}$ ratio. This could have been because of higher As acquisition and lower Fe concentrations in the shoots of AM plants than in the nonmycorrhizal controls in high $\mathrm{P}$ soil, resulting in symptoms of As phytotoxicity and Fe deficiency, which might explain the poor growth of the host plants.

The increase of plant As concentrations with $\mathrm{P}$ addition may be linked to the soil As release and changes in the SAR of As (Tables 2 and 4). Because arsenate and phosphate are chemical analogues, it has been demonstrated that application of phosphate fertilizer to As-contaminated soils can enhance As release into the soil solution through

Table 4 Soil pH, water-extractable $P$, and As concentrations at the experimental harvest

\begin{tabular}{|c|c|c|c|c|}
\hline \multirow[t]{2}{*}{ Inoculation treatment } & \multirow[t]{2}{*}{ P level $(\mathrm{mg} / \mathrm{kg})$} & \multirow[t]{2}{*}{ Soil pH } & \multicolumn{2}{|c|}{ Water extractable fractions } \\
\hline & & & $\mathrm{P}(\mathrm{mg} / \mathrm{kg})$ & As $(\mathrm{mg} / \mathrm{kg})$ \\
\hline \multirow[t]{2}{*}{ Uninoculated } & 0 & $7.65 \pm 0.01^{\mathrm{b}^{*}}$ & $4.1 \pm 0.1^{\mathrm{c}}$ & $48.4 \pm 0.6^{\mathrm{c}}$ \\
\hline & 100 & $7.51 \pm 0.03^{\mathrm{c}}$ & $15.4 \pm 0.7^{\mathrm{b}}$ & $73.3 \pm 2.1^{\mathrm{a}}$ \\
\hline \multirow[t]{2}{*}{ Inoculated } & 0 & $7.75 \pm 0.03^{\mathrm{a}}$ & $3.9 \pm 0.2^{\mathrm{c}}$ & $60.7 \pm 1.5^{\mathrm{b}}$ \\
\hline & 100 & $7.76 \pm 0.01^{\mathrm{a}}$ & $17.5 \pm 0.2^{\mathrm{a}}$ & $77.0 \pm 2.4^{\mathrm{a}}$ \\
\hline
\end{tabular}

*Means \pm SE $(n=3)$ in same column with different letters differ significantly $(P<0.05)$. 
competitive exchange, resulting in an increase in the availability of soil As (Woolson et al., 1973; Cao and Ma, 2004). In accordance with this, $P$ amendment increased $\mathrm{P} /$ As ratios in uninoculated plants (especially the roots), but reduced $\mathrm{P} / \mathrm{As}$ ratios in the inoculated ones (Table 2), and this may be because of the higher SAR ratio of $\mathrm{P}$ to As by nonmycorrhizal plants and lower SAR ratio of $\mathrm{P}$ to As by the mycorrhizal ones, with $\mathrm{P}$ addition (data not shown).

In the present study, the root biomass was greatly increased by mycorrhiza, and the root length of AM plants was up to 3.4 times that of nonmycorrhizal controls in low-P soil. In general, enhanced mineral acquisition by AM plants has usually been associated with an increased root absorbing area, because of the extension into the soil by the extraradical mycelium (Clark and Zeto, 1996). Nevertheless, the enlarged root systems of mycorrhizal plants also contribute essentially to nutrient acquisition. The beneficial mycorrhizal effects on plant acquisition of mineral nutrients ( $\mathrm{P}, \mathrm{Fe}, \mathrm{Mn}, \mathrm{Cu}$, and $\mathrm{Zn}$ ) are more pronounced under conditions of low $\mathrm{P}$ supply, and $\mathrm{P}$ addition may largely decrease hyphal length density, mycorrhizal dependency (data not shown), and uptake of $\mathrm{Fe}, \mathrm{Mn}, \mathrm{Cu}$, and $\mathrm{Zn}$. It may be explained by the suppression of extraradical hyphal development and reduced AM colonization (Liu et al., 2000; Azcón et al., 2003) with higher available soil P levels.

In summary, the present study lent further evidence for the significance of AM fungi in plant adaptation to As contaminations. Moreover, it also indicated the importance of appropriate fertilizer management in the ecological restoration of contaminated soils. Application of P fertilizer may add to the environmental risk of As contamination, and essentially cut off the benefits of mycorrhizal association. The interactions of AM fungi with phosphates have a critical effect on the plant uptake of As and other nutrients, and therefore deserve systemic studies.

\section{Conclusions}

The present study has further demonstrated the important role that AM plays in plant resistance to As contamination, both by depressing As translocation from roots to shoots and by the preferential uptake of $\mathrm{P}$ over As, and enhancing host plant growth in soils with the status of low-P availability AM fungi may therefore assist in the ecological restoration of As-contaminated soils. However, as massive $\mathrm{P}$ application can inhibit mycorrhizal dependency and host plant growth, accelerate soil As release, and induce $\mathrm{Fe}$ deficiency, caution is required when attempting to combine mycorrhizal technology with agronomic practices, to maximize the positive effects of mycorrhizal association.

\section{Acknowledgements}

The authors would like to thank Prof. Zhu Yong-Guan for his critical comments on the manuscript, and also Ms Dong Yan for her assistance with the chemical analysis of the samples.

\section{References}

Acharyya S K, Chakraborty P, Lahiri S et al., 1999. Arsenic poisoning in the Ganges delta[J]. Nature, 401: 545-546.

Azcón R, Ambrosano E, Charest C, 2003. Nutrient acquisition in mycorrhizal lettuce plants under different phosphorus and nitrogen concentration[J]. Plant Sci, 165: 1137-1145.

Cai B S, Chen T B, Liao X Y et al., 2004. Arsenic concentrations in soils and vegetables and their risk assessments in highly contaminated area in Hunan Province[J]. Acta Ecologica Sinica, 24(4): 711-717.

Cao X, Ma L Q, Shiralipour A, 2003. Effects of compost and phosphate amendments on arsenic mobility in soils and arsenic uptake by the hyperaccumulator Pteris vittata L.[J]. Environ Pollut, 126: 157-167.

Cao X, Ma L Q, 2004. Effects of compost and phosphate on plant arsenic accumulation from soils near pressure-treated wood[J]. Environ Pollut, 132: 435-442.

Chen B D, Zhu Y G, Smith F A et al., 2006. Effects of arbuscular mycorrhizal inoculation on uranium and arsenic accumulation by Chinese brake fern (Pteris vittata $\mathrm{L}$.) from a uranium mining-impacted soil[J]. Chemosphere, 62: 1464-1473.

Chen B D, Xiao X Y, Zhu Y G et al., 2007. The arbuscular mycorrhizal fungus Glomus mosseae gives contradictory effects on phosphorus and arsenic acquisition by Medicago sativa Linn[J]. Sci Total Environ, 379(2/3): 226-234.

Clark R B, Zeto S K, 1996. Mineral acquisition by mycorrhizal maize grown on acid and alkaline soil[J]. Soil Biol Biochem, 28: 1495-1503.

Dixon H B F, 1997. The biochemical action of arsenic acids especially as phosphate analogues[M]. In: Advances in inorganic chemistry (Sykes A. G., ed.). San Diego: Academic Press. 191-228.

Fitz W J, Wenzel W W, 2002. Arsenic transformations in the soil-rhizosphere-plant system: fundamentals and potential application to phytoremediation[J]. J Biotechnol, 99: 259278.

GenStat Committee, 2002. The guide to GenStat[Z]. release 6.1. Hemel Hempstead: VSN International.

Giovannetti M, Mosse B, 1980. Evaluation of techniques for measuring vesicular arbuscular mycorrhizal infection in roots[J]. New Phytol, 84: 489-500.

Gonzalez-Chavez C, Harris P J, Dodd J et al., 2002. Arbuscular mycorrhizal fungi confer enhanced arsenate resistance on Holcus lanatus[J]. New Phytol, 155: 163-171.

Harley J L, 1989. The significance of mycorrhiza[J]. Mycol Res, 92: 129-139.

Harrison M J, Dewbre G R, Liu J, 2002. A phosphate transporter from Medicago truncatula involved in the acquisition of phosphate released by arbuscular mycorrhizal fungi[J]. Plant Cell, 14: 2413-2429.

Jones M D, Durall D M, Tinker P B, 1998. A comparison of arbuscular and ectomycorrhizal Eucalyptus coccifera: growth response, phosphorus uptake efficiency and external hyphal production[J]. New Phytol, 140: 125-134.

Lambkin D C, Alloway B J, 2003. Arsenate-induced phosphate release from soils and its effect on plant phosphorus[J]. Water Air Soil Pollut, 144: 41-56.

Liu A, Hamel C, Hamilton R I et al., 2000. Acquisition of Cu, Zn, $\mathrm{Mn}$ and $\mathrm{Fe}$ by mycorrhizal maize (Zea mays L.) grown in soil at different $\mathrm{P}$ and micronutrient levels[J]. Mycorrhiza, 9: 331-336.

Liu Y, Zhu Y G, Chen B D et al., 2005. Yield and arsenate uptake of arbuscular mycorrhizal tomato colonized by Glo- 
mus mosseae BEG167 in As spiked soil under glasshouse conditions[J]. Environ Int, 31: 867-873.

Meharg A A, Macnair M R, 1990. An altered phosphate uptake system in arsenate tolerant Holcus lanatus L.[J]. New Phytol, 116: 29-35.

Meharg A A, Macnair M R, 1992. Suppression of the highaffinity phosphate-uptake system: a mechanism of arsenate tolerance in Holcus lanatus L.[J]. J Exp Bot, 43: 519-524.

Meharg A A, Cairney J W G, 1999. Co-evolution of mycorrhizal symbionts and their hosts to metal contaminated environments[J]. Adv Ecol Res, 30: 70-112.

Melamed R, Jurinak J J, Dudley L M, 1995. Effect of adsorbed phosphate on transport of arsenate through an oxisol[J]. Soil Sci Soc Am J, 59: 1289-1294.

Newman E I, 1966. A method of estimating the total length of root in a sample[J]. J Appl Ecol, 3: 139-145.

Peryea F J, Kammereck R, 1997. Phosphate-enhanced movement of arsenic out of lead arsenate-contaminated topsoil and through uncontaminated subsoil[J]. Water Air Soil Pollut,
93: 243-254.

Phillips J M, Hayman D S, 1970. Improved procedures for clearing roots and staining parasitic and vesicular arbuscular mycorrhizal fungi for rapid assessment of infection[J]. Trans Br Mycol Soc, 55: 158-161.

Sharples J M, Meharg A A, Chambers S M et al., 2000a. Symbiotic solution to arsenic contamination[J]. Nature, 404: 951-952.

Sharples J M, Meharg A A, Chambers S M et al., 2000b. Mechanism of arsenate resistance in the ericoid mycorrhizal fungus Hymenoscyphus ericae[J]. Plant Physiol, 124: 1327-1334.

Smith S E, Read D J, 1997. Mycorrhizal symbiosis[M]. 2nd ed. London: Academic Press.

Smith E, Naidu R, Alston A M, 1998. Arsenic in the soil environment: A review[J]. Adv Agron, 64: 149-195.

Woolson E A, Axley J H, Kearney P C, 1973. The chemistry and phytotoxicity of arsenic in soils: II. Effects of time and phosphorus[J]. Soil Sci Soc Am J, 37: 254-259 